\title{
PEDESET NIJANSI SLOBODE
}

\section{Parapolitika: kulturna sloboda i hladni rat, Haus der Kulturen der Welt, Berlin, 3. studenoga 2017.- 8. siječnja 2018.}

DOI: $10.31664 /$ zu.2018.102.06

Kada govorimo o posleratnoj umetnosti pedesetih i šezdesetih godina, govorimo o političkoj kompleksnosti tek nastajućih (samo)organizovanih ili političkih mreža, stvaranju infrastruktura za pojavu umetničkog internacionalizma širih razmera kroz razmene i putovanja, kao i promenljivim pozicijama intelektualaca i umetnika tokom hladnog rata. To je društveni i kulturni setting u kome se odigrava ono što autori izložbe Kulturna sloboda i hladni rat (Paz Gevara [Paz Guevara], Nida Gus [Nida Ghouse], Antonia Majača i Anselm Franke) nazivaju Parapolitikom, ${ }^{1}$ koristeći se upravo terminom koji označava snagu koalicija i mreža, političkih aktivnosti koje su autonomne u odnosu na mainstream držav-

Više o izložbi i programima: „Parapolitics: Cultural Freedom and the Cold War”. ne i nacionalne politike, a opet, ključne u sprovođenju onoga što zovemo $d u$ boka politika.

U sličnom duhu, Patrik Iber [Patrick Iber], autor knjige Niti mir niti sloboda (Neither Piece nor Freedom), svoje obraćanje u okviru izložbe počinje vicem iz vremena hladnog rata: „Svaka organizacija koja u svom nazivu nosi reč Sloboda u suštini predstavlja instrument Američke moći: Nacionalni komitet za slobodnu Evropu je sponzorisala CIA, Radio Slobodna Evropa je podržavala CIA, dok je Kongres za slobodu kulture inicirala CIA", komentarišući kako ova šala možda i nije duhovita, upravo zato što je istinita. ${ }^{2}$ Izložba Parapolitika, međutim, ne želi da nam saopšti „veliku istinu” i otvori oči da bismo videli pozadinu stvari, već se upravo

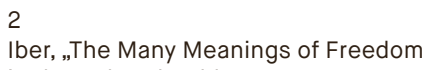
in the Cultural Cold War”. bavi tim proporcijama i fluktuacijama između vica i stvarnosti, ideologije i istine, kroz aktivnosti i učinke Kongresa za slobodu kulture 1950-1967 (CCF), čija je široka mreža kancelarija operisala po čitavom svetu u pravcu promovisanja slobode i moderne umetnosti.

$\rightarrow$

\section{Jelena Vesić}




\section{Parapolitics: Cultural Freedom and the Cold War, Haus der Kulturen der Welt, Berlin, November 3, 2017 - January 8, 2018}

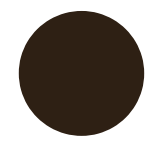

DOI: 10.31664/zu.2018.102.06

When we talk about postwar art of the I950s and I96os, we are talking about the political complexity of emerging (self-)organised or political networks, the establishment of infrastructure for a wider artistic internationalism through exchange and travel, as well as the changing attitudes of intellectuals and artists during the Cold War. This is the social and cultural setting for what the authors of the exhibition Cultural Freedom and the Cold War (Paz Guevara, Nida Ghouse, Antonia Majača and Anselm Franke) call Parapolitics, ${ }^{1}$ using the term that signifies the strength of coalitions and networks, of political activities that are autonomous in relation to the mainstream state and national politics, and yet are crucial in conducting what we call deep politics.

In a similar vein, Patrick Iber, the author of Neither Peace nor Freedom, started his lecture held as part of the exhibition with a Cold War joke: "Any organisation with the word 'freedom' in its name was in fact an instrument of US state power: the National Committee for a Free Europe - CIA sponsored, Radio Free Europe - CIA backed, and, of course, the Congress for Cultural Freedom-CIA-dependent," adding that the joke might not be funny precisely because it was true. ${ }^{2}$ However, the Parapolitics exhibition does not aspire to reveal "the big truth" and open our eyes Iber, "The Many Meanings of Freedom to the hidden causes of things, but focuses on these proportions and fluctuations between jokes and reality, between the ideology and the truth, as seen through the activities and impacts of the Congress for Cultural Freedom I950-I967 (CCF), whose wide network of offices operated worldwide with the aim of promoting freedom and modern art.

$\rightarrow$

More on the exhibition and its programmes: "Parapolitics: Cultural Freedom and the Cold War." in the Cultural Cold War." 


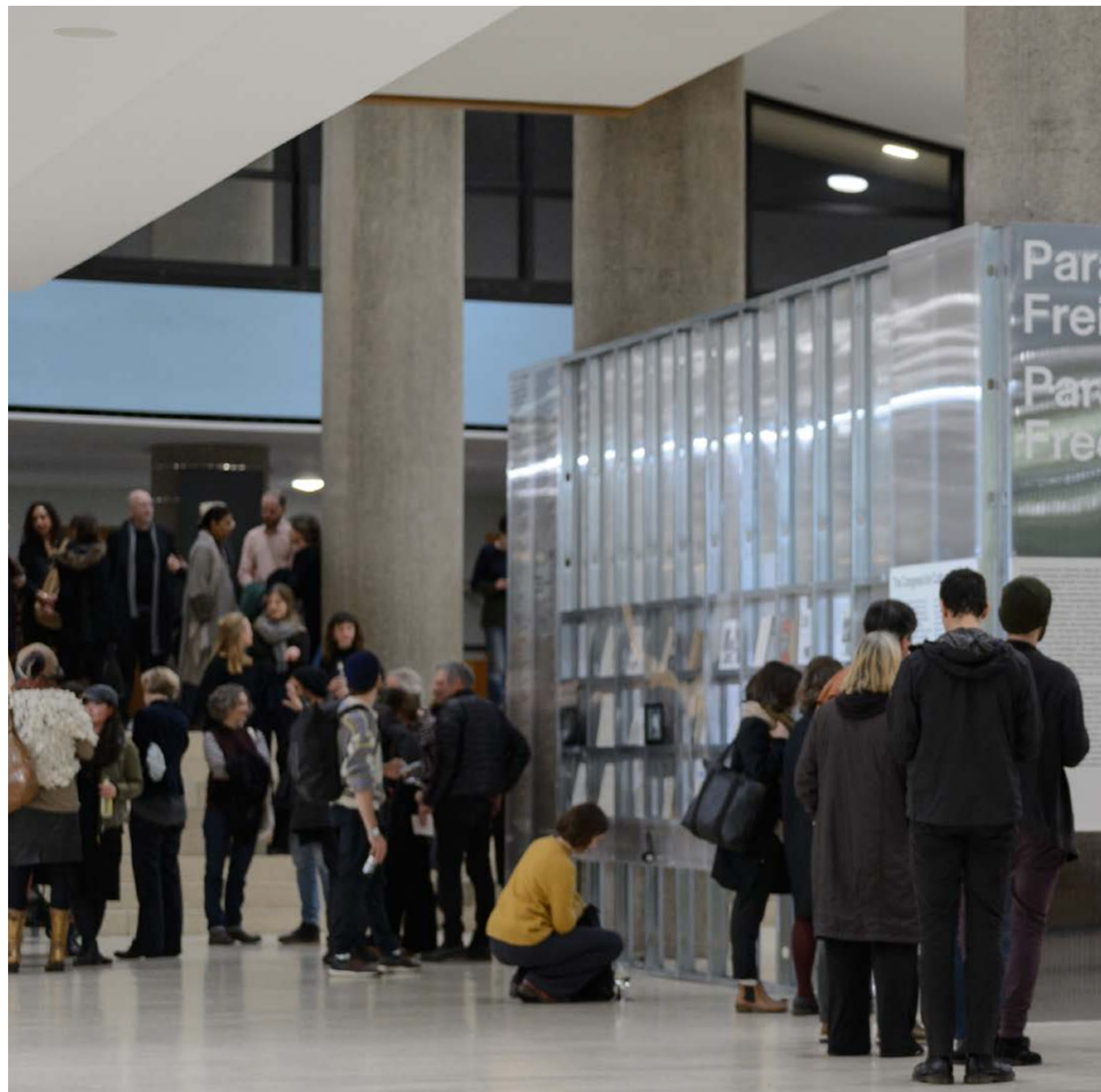




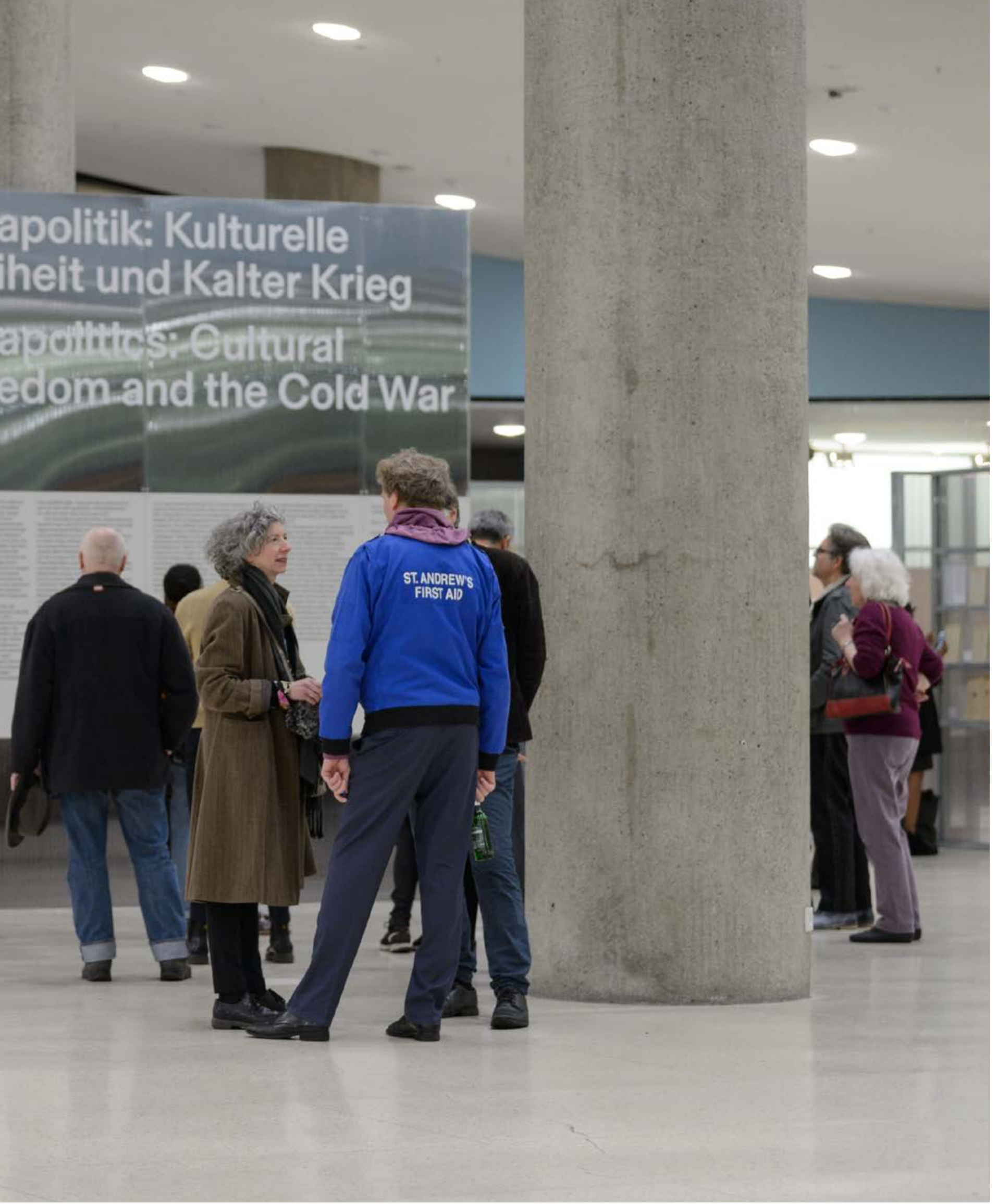


Krajem šezdesetih godina je otkriveno da je CIA umešana u ove procese i ugled organizacije je narušen. Kongres za slobodu kulture je podržavao veliki broj umetničkih programa u čitavom svetu-od Latinske Amerike, preko Afrike i jugozapadne Azije, do Evrope i natrag-razvijajući mrežu žurnala, konferencija i izložbi koje su promovisale „univerzalni” jezik modernizma.

Uz pomoć arhivskih materijala, umetničkih radova, rekonstrukcija ili simulacija izložbi koje su se sprovodile ovim kanalima, izložba Parapolitika istražuje ideološku pozadinu te „univerzalnosti” tvrdeći da je maskiranjem ideoloških procesa vezanih za razvoj moderne umetnosti modernizam postao neka vrsta aistoričnog fenomena; da je kanonizacija njegove univerzalnosti upravo ukidanje politike i istorije. Arhivski materijali uključuju i značajne posleratne žurnale kao što su Encounter ili Partisan Review, Black Orpheus i Transition iz Nigerije, Hiwar iz Libana, Cultura y Lybertad i Cuadernos iz Latinske Amerike, South Africa in Exile i drugi.

Delovanje Kongresa za slobodu kulture i posredno CIA je kroz ovu izložbu takođe situirano i u lokalni kontekst kroz institucionalnu refleksiju HKW-a (Haus der Kulturen der Welt) koji je u to vreme operisao i kao Kongresna hala. Kongres je inaugurisan u Berlinu 1950. godine, a njegovo uspostavljanje je predvodila grupa tzv. antitotalitarnih intelektualaca predvođena američkim novinarom Melvinom Laskijem [Melvin Lasky], osnivačem zapadnonemačkog žurnala Der Monat; antitotalitarizam ovde treba shvatiti kao skup različitih antistaljinističkih frakcija čiji je ideološki valer pokrivao skalu od levih do liberalno-desnih opcija koje su otvorile prostor globalnom postkomunističkom konsenzusu kao predtekstu savremene epohe. Kongres za slobodu kulture je svoju desetu godišnjicu proslavio u samom HKW-u, tako da su pitanja hladnog rata, te diskrepancije između ideje slobode i materijalne realnosti kroz koju je ta ideja konstruisana, tematizovane kroz ovu izložbu i kao neka vrsta institucionalne refleksije i kritičke samoistorizacije. Kustosko istraživanje postavlja akcent na metapodatke-pojedinačni artefakti i umetnička dela su radije tu da ukažu na narative kroz koje je moderna umetnost konstituisana. Izložba bi se mogla zamisliti i kao neka vrsta stalne postavke HKW-a.

Izloženi materijali pokazuju sliku stvari koja nije crno-bela, već radije sugeriše potragu za nijansama propagande i značenja. lako kritička iščitavanja modernizma, od kojih je najpopularnije ono Gilboovo [Guilbaut] Kako je New York ukrao ideju moderne umetnosti, ${ }^{3}$ u osnovi tvrde da je kanonizacija zapadne modernosti proizvod procesa uspostavljanja američke kulturne i političke hegemonije, vidimo da je Kongres za slobodu kulture takođe stajao i iza umetničkih i intelektualnih projekata koji se nisu uklapali u politiku američkog liberalizma i koji su, neretko, otvoreno inklinirali levim idejama. Ako je po ubeđenjima pokretača i saradnika Kongresa sloboda bila označavana apstrakcijom i modernizmom, a državni diktat nad umetnošću reakcionarnim akademskim realizmom, ovakvi označitelji su bili klizni, jer je veći broj avangardnih umetnika, koji su predstojali posleratnim apstrakcionistima i često im bili polazište, stajao iza projekta socijalizma. Ne čudi da se u vremenu tematski obuhvaćenom izložbom Parapolitika pojavljuju i tekstovi značajnijih istoričara umetnosti, kritičara i kustosa koji se bave dubljom analizom apstraktne umetnosti i pojmovima slobode i totalitarizma u ovom ključu: od Prirode moderne umetnosti Majera Šapira [Mayer Schapiro], ${ }^{4}$ preko danas kanonskog teksta Avangarda i Kič Klementa Grinberga [Clement Greenberg], ${ }^{5}$ do članka Alfreda Bara [Alfred Barr] iz 1952. koji otvoreno postavlja „hladnoratovsko pitanje" Da li je moderna umetnost komunistička? u naslovu teksta. ${ }^{6}$

Kroz brojne narative i studije slučajeva izložba Parapolitika prikazuje hladni rat u, preko i kroz kulturu kao borbu za „misli i osećanja” intelektualaca i umetnika koja se vodila u ringu za supremaciju kapitalističkog ili socijalističkog bloka i uplitala se u procese sticanja političke nezavisnosti zemalja „trećeg sveta”.

\section{3}

Guilbaut, How New York Stole the Idea of Modern Art.

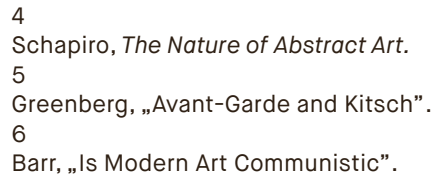


CIA's involvement in these processes was discovered in late I96os, and it damaged the organisation's reputation. The Congress for Cultural Freedom supported many artistic programmes worldwide - from Latin America, through Africa and Southwest Asia to Europe and back-and developed a network of journals, conferences and exhibitions that promoted a "universal" language of modernism.

Presenting archival materials, together with the contemporary artworks, and reconstructions or simulations of exhibitions organised through the CCF channels, the curators of the Parapolitics exhibition investigated the ideological background of this "universality" by claiming that the camouflaging of ideological processes tied to the development of modern art made modernism a sort of ahistorical phenomenon; that the canonisation of its universality means the abolition of politics and history. The exhibition-research includes important postwar journals as platforms and references for such claim: Encounter and Partisan Review that operated internationally, Black Orpheus and Transition from Nigeria, Hiwar from Lebanon, Cultura y Lybertad and Cuadernos from Latin America, South Africa in Exile and many others.

Furthermore, this exhibition situated the work of the Congress for Cultural Freedom, and indirectly the CIA, in the local context through institutional reflection on the HKW (Haus der Kulturen der Welt), which operated as the Congress' hall at the time. The Congress was inaugurated in Berlin in I950, and its establishment was spearheaded by a group of so called anti-totalitarian intellectuals, led by the American journalist Melvin Lasky, founder of the West-German journal Der Monat; anti-totalitarianism should here be understood as an assembly of various anti-Stalinist fractions whose ideological values covered the scale between left and liberal-right options, and which cleared the way for a global post-communist consensus as an ideological template for the modern era. The Congress for Cultural Freedom celebrated its tenth anniversary in the HKW itself, which is why the issues of the Cold War, as well as the discrepancies between the idea of freedom and the material reality through which this idea is constructed, have been thematised through this exhibition as a sort of institutionalised reflexion and critical self-historization. Curatorial exploration puts the accent on the meta-data-individual artefacts and works of art are presented mainly to draw attention to the narratives through which modern art has been constituted. The exhibition could also be thought of as some sort of HKW's permanent display.

The exhibition material paints a picture of a reality that is not black and white, but suggests a search for nuances of propaganda and meaning. Although critical readings of modernism, the most famous of which is Guibault How New York Stole 3 the Idea of Modern Art, ${ }^{3}$ basically claim that the canonisation of Western modernity Guilbaut, How New York Stole the Idea results from the process of establishing American cultural and political hegemo- of Modern Art. ny, we can see that the Congress for Cultural Freedom also stood behind artistic and intellectual projects that did not fit into the politics of American liberalism and that were often openly inclined to leftist ideas. Even if Congress' initiators and associates labelled freedom as an abstraction and a modernism, and state dictate over art as reactionary academic realism, such markers were not fixed because the majority of avant-garde artists, who preceded post-war abstractionists and were often their starting point, stood behind the socialist project. It is no surprise that the period covered by the Parapolitics exhibition was also a time when some distinguished art historians, critics and curators wrote texts that deal with a deeper analysis of abstract art and the concepts of freedom and totalitar- 4 ianism in this key: from Mayer Schapiro's The Nature of Abstract Art, ${ }^{4}$ through the
now iconic text Avant-garde and Kitsch by Clement Greenberg, ${ }^{5}$ to Alfred Barr's now iconic text Avant-garde and Kitsch by Clement Greenberg, to Alfred Barr's
I952 article that openly raises the "Cold War question" in its very title asking Is Modern Art Communistic.. ${ }^{6}$

\author{
Schapiro, The Nature of Abstract Art. \\ Greenberg, "Avant-Garde and Kitsch.” \\ Barr, "Is Modern Art Communistic."
}




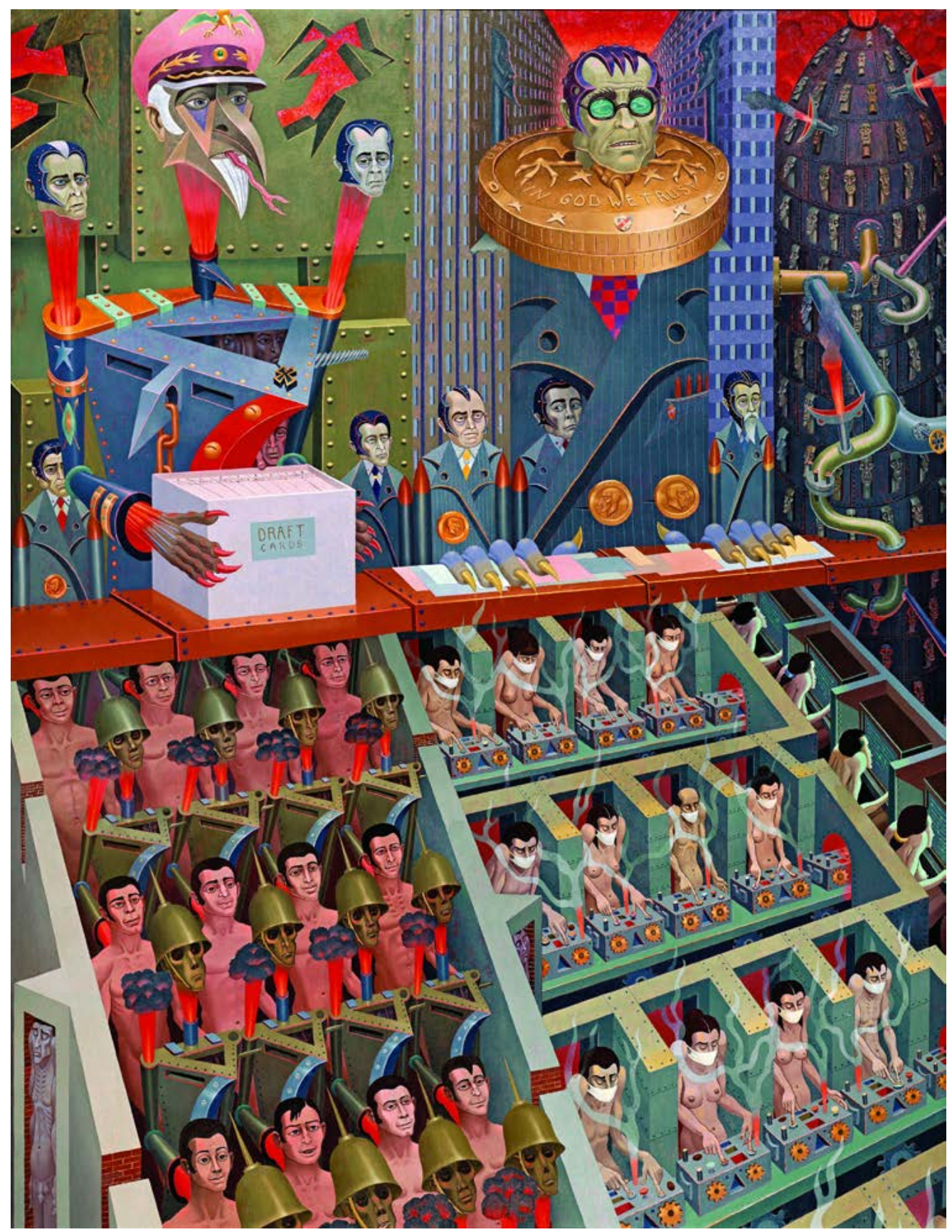

Irving Norman (1906-1989), M.F.I. Complex, 1981. Ulje na platnu, $254 \times 193$ cm ๑ Crocker Art Museum Association, Sacramento. Ljubaznošću Galerije Michael Rosenfeld LLC, New York, NY / Irving Norman (1906-1989), M.F.I. Complex, 198I. Oil on canvas, $254 \times 193$ cm (c) Crocker Art Museum Association, Sacramento. Courtesy of Michael Rosenfeld Gallery LLC, New York, NY 


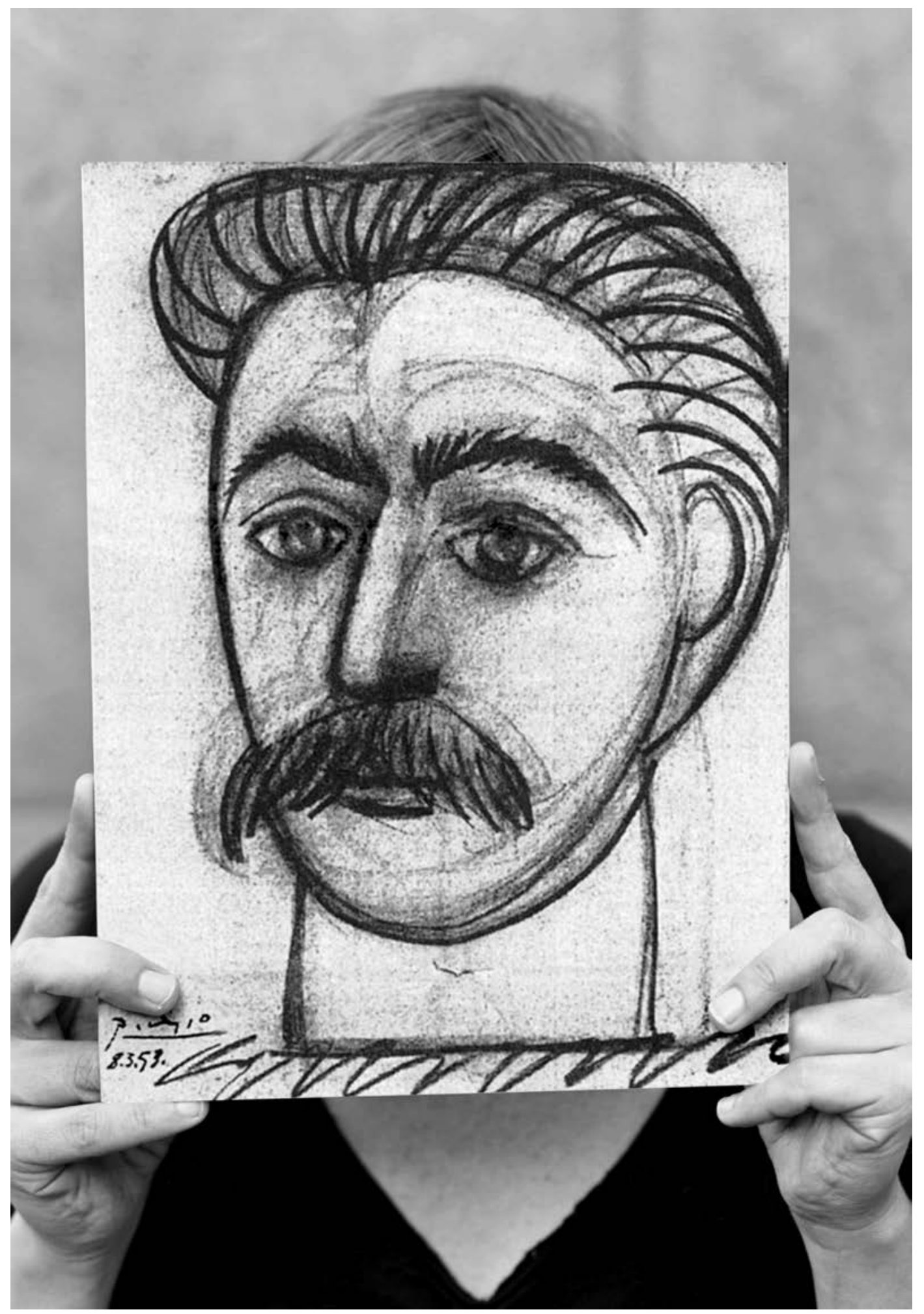

Lene Berg, Staljin prema Picassu ili portret žene s brkovima, pročelni banner izložbe, 2008.

Ljubaznošću umjetnice / Lene Berg, Stalin by Picasso or Portrait of Woman with Moustache, Façade-banner, 2008. Courtesy of the Artist 
Govorimo o liniji sukoba koja je u estetsko-političkom smislu delila modernističku i apstraktnu umetnost Zapada u odnosu na realizam i figuraciju umetnosti Istočnog bloka. Prema Tomasu Brejdenu [Thomas Braden], istaknutom članu Kongresa kao „tajne akcije” CIA, kulturni hladni rat je predstavljao borbu za Picassov um. Drugim rečima, čitava stvar je bila „u službi” procesa konstituisanja kanona modernizma, odnosno vlasništva nad nasleđem i suštinom avangardi i predratnih modernizama.

Supremacija zapadnog kanona umetnosti, moderne i apstraktne umetnosti, zasnivala se na ideološkoj borbi čije su ključne reči bile sloboda i totalitarizam. Tačnije, pobednički zapadni kanon je konstituisan kroz prisvajanje pojma slobode i uvođenja oznake totalitarno za sve druge prakse koje se nisu zasnivale na konceptima individualnih sloboda i singularnog autorskog izraza. Trope „slobodni svet” i „totalitarne države” prikazane su na izložbi Parapolitika kroz delovanje Franca Borkenaua [Franz Borkenau], Ernsta Noltea [Ernst Nolte], Fridriha A. Hajeka [Friedrich A. Hayek] i Karla Popera [Karl Popper]. Ovaj deo postavke ponajviše sumira čitanja kustoskinje Antonije Majače i povezuje delovanje ranih proponenanta teorije totalitarizama tridesetih godina, zasnovane na komparativnoj analizi fašizma i komunizma, koja je postepeno vodila mitu o kraju ideologije. U nastavku, Poperova filozofija „otvorenog društva” je postala ključna referenca za kasnije kulturno-političko delovanje Džordža Soroša [George Soros] i Centara za savremenu umetnost koji su konstituisali polje istočnoevropske umetnosti u vremenu političke tranzicije nakon kraja hladnog rata, koja je istovremeno i tranzicija ka savremenosti.

Izložba Parapolitika je karakteristična i po tome što nudi globalni pogled na hladni rat koji nije formiran isključivo kroz „transatlantsku” vizuru, već u svojoj kompleksnosti i nijansama koje uključuju višeglasje i govor iz raznih pravaca. Tako Ezekiel Falele [Es'kia Mphahlele], jedan od osnivača Mbari kluba umetnika i pisaca (osnovanog 1961. godine u Ibadanu, Nigerija) i šef CCF programa za Afriku, piše nakon događaja 1967: „U Africi nismo ništa uradili sa znanjem da novac dolazi od CIA; niti smo uradili išta što ne bismo uradili da je novac stigao iz drugih izvora". 8 Umetnički radovi Mbari grupe i grupe Beat in Spider's Bush (1984.) odbijaju da budu jednostavno svrstani u kategorije zapadne apstrakcije ili istočnog realizma. Jasno je da zemlje „trećeg sveta” odbijaju da budu žrtve umešanosti CIA i puki pratioci evroameričkog modela moderne umetnosti.

Konačno, izložba Parapolitika čini vidljivim kontrast koji je postojao između promovisane demokratije i slobode zapadnog sveta i rasne opresije „kod kuće” koja je i dalje bila aktuelna, naročito u američkom kontekstu. U svom izlaganju u okviru izložbe Kodvo Ešun [Kodwo Eshun], član Otholit grupe, govori o tome kako crni proletarijat „nosi snagu nepripadanja koja nagriza samoreprezentaciju komunizma kao organske kuće za čitavu radničku klasu”. 9 •
Više o ovome: Vesić, Majača, „The Totalitarian Paradigm and Making of Contemporary Art”. See also: Vesić, „The Annual Summit of NonAligned Art Historians", 28-51.

Izjava iz 1967. godine, tekst na izložbi, proširena legenda uz časopis Black Orpheus.

Eshun, „'The Colony is a Prison': Richard Wright's Political Diagnostics on the 'Redemption of Africa' in the Gold Coast". [prev. J. Vesić] 


\section{Even if Congress' initiators and associates labelled}

freedom as an abstraction and a modernism, and state dictate over art as reactionary academic realism, such markers were not fixed because the majority of avant-garde artists, who preceded post-war abstractionists and were often their starting point, stood behind the socialist project 
Ako je po ubeđenjima pokretača i saradnika Kongresa sloboda bila označavana apstrakcijom i modernizmom, a državni diktat nad umetnošću reakcionarnim akademskim realizmom, ovakvi označitelji su bili klizni, jer je veći broj avangardnih umetnika, koji su predstojali posleratnim apstrakcionistima i često im bili polazište, stajao iza projekta socijalizma 
Through numerous narratives and case studies, the Parapolitics exhibition portrays the Cold War in, via and through culture as the fight for "hearts and minds" of intellectuals and artists that was fought for the prize of supremacy of the Capitalist or Socialist bloc, and which interfered in the processes of gaining political independence of "Third World" countries. We are talking about a line of conflict which, in the aesthetic and political sense, divided Western modernist and abstract art from realism and the figuration of art of the Eastern Bloc. According to Thomas Braden, a distinguished member of the Congress as CIA's "covert action arm," cultural Cold War was a battle for Picasso's mind. In other words, the whole thing was "in the service" of the process of continuing the modernist cannon, or rather of the ownership over the legacy and the essence of avant-garde and prewar modernisms.

The supremacy of the Western art canon, of modern and abstract art, was based on the ideological fight whose keywords were freedom and totalitarianism. More accurately, the winning Western canon was constituted through the appropriation of the term freedom and the introduction of the totalitarian label for all other practices that were not based on the concepts of individual freedoms and singular artistic expression. The tropes "free world" and "totalitarian states" were represented at the exhibition through the work of Franz Borkenau, Ernst Nolte, Friedrich A. Hayek and Karl Popper. This part of the exhibition mostly summarised the readings of the curator Antonia Majača and, based on the comparative analysis of fascism and communism, connected the work of the early proponents of the totalitarian idea from the I930s which gradually led to the myth of the end of ideology. In the second part, Popper's philosophy of the "open society" became a key reference for subsequent cultural-political activities of George Soros and the Centers for Contemporary Art which constituted the field of Eastern European art at a time of political transition following the end of the Cold War, a time that 7 also presented transition to the era of the global contemporaneity.

More on this topic: Vesić, Majača,

"The Totalitarian Paradigm and Making

The Parapolitics exhibition is characterised by its global approach and overview of "The Annual Summit of Non-Aligned the Cold War era that was not formed through the usual "transatlantic" perspec- Art Historians," 28 -5I.

tive, but through the polyphony of voices and gazes, complexities and nuances and multiplicity of perspectives. Thus Ezekiel Mphahlele, one of the founders of the Mbari club of artists and writers (established in I96I in Ibadan, Nigeria) and the director of the CCF's African program, wrote after the events of I967: "In Africa, we have done nothing with the knowledge that the money came from the CIA; nor have we done anything we would not have done if the money had come from elsewhere." ${ }^{8}$ Artworks by the Mbari group and the Beat in Spider's Bush (I984) repudiate the easy classification into the categories of Western abstraction or Eastern realism. It is clear that "Third World" countries refused to be victims of CIA's involvement or mere spectators of the Euro-American model of modern art.

Statement from 1967 , text from the exhibition, expanded caption for the journal Black Orpheus.

Finally, the Parapolitics exhibition makes visible the contrast that existed between the lauded democracy and freedom of the Western world and the still current racial oppression "at home," especially in the US context. In the speech he gave as part of the exhibition, Kodwo Eshun, a member of the Otholit group, talked about how the black proletariat "bears a force of un-belonging that corrodes com- 9 munism's self-representation as the natural home to all working classes." 9

Eshun, “The Colony is a Prison': Richard

Wright's Political Diagnostics on the

'Redemption of Africa' in the Gold Coast." 


\section{POPIS LITERATURE / BIBLIOGRAPHY}

Barr, Alfred. „Is Modern Art Communistic”. New York Times Magazine,

14. prosinca 1952./ December 14, 1952, 22-23, 28-30.

Eshun, Kodwo. „'The Colony is a Prison': Richard Wright's Political Diagnostics on the 'Redemption of Africa' in the Gold Coast", Haus der Kulturen der Welt, 16. prosinca 2017./December 16, 2017. https://www.hkw.de/en/app/mediathek/ video/62317 (pristupljeno 3. svibnja 2018./last accessed on May 3, 2018).

Greenberg, Clement. „Avant-Garde and Kitsch”. Partisan Review 5 (1939): 34-49.

Guilbaut, Serge. How New York Stole the Idea of Modern Art. Chicago: University of Chicago Press, 1985.

Iber, Patrick. „The Many Meanings of Freedom in the Cultural Cold War”. Haus der Kulturen der Welt, 15. prosinca 2017./December 15, 2017. https://www.hkw.de/ en/app/mediathek/video/62402 (pristupljeno 3. svibnja 2018./last accesed on May 3,2018$)$.

„Parapolitics: Cultural Freedom and the Cold War”. Haus der Kulturen der Welt. https://www.hkw.de/en/programm/projekte/2017/parapolitics/ parapolitics_start.php (pristupljeno 3. svibnja 2018./last accessed on May 3, 2018).

Schapiro, Meyer. The Nature of Abstract Art. New York: American Marxist Association, 1937.

Vesić, Jelena. „The Annual Summit of Non-Aligned Art Historians”, 28-51. U/In: Extending the Dialogue, ur./ed. Urška Jurman, Christiane Erharter, Rawley Grau. Ljubljana: Igor Zabel Association for Culture and Theory-Berlin: Archive Books - Vienna: ERSTE Foundation, 2016.

Vesić, Jelena, Majača Antonia. „The Totalitarian Paradigm and the Making of Contemporary Art", Haus der Kulturen der Welt, 10. prosinca 2017./

December 10, 2017. https://www.hkw.de/en/programm/projekte/veranstaltung/ p_136719.php (pristupljeno 3. svibnja 2018./last accessed on May 3, 2018). 
